\title{
Terrestrial carbon sinks in the Brazilian Amazon and Cerrado region predicted from MODIS satellite data and ecosystem modeling
}

\author{
C. Potter ${ }^{1}$, S. Klooster ${ }^{2}$, A. Huete ${ }^{3}$, V. Genovese ${ }^{2}$, M. Bustamante ${ }^{4}$, L. Guimaraes Ferreira ${ }^{5}$, R. C. de Oliveira Jr. ${ }^{6}$, and \\ R. Zepp ${ }^{7}$ \\ ${ }^{1}$ NASA Ames Research Center, Moffett Field, CA, USA \\ ${ }^{2}$ California State University Monterey Bay, Seaside, CA, USA \\ ${ }^{3}$ University of Arizona, Tucson, AZ, USA \\ ${ }^{4}$ Universidade de Brasilia, Brasilia, Brazil \\ ${ }^{5}$ Universidade Federal de Goias, Goiânia, Goiás, Brazil \\ ${ }^{6}$ EMBRAPA Amazonia Oriental, Belém, Pará, Brazil \\ ${ }^{7}$ US Environmental Protection Agency, Athens, GA, USA
}

Received: 14 November 2008 - Published in Biogeosciences Discuss.: 16 January 2009

Revised: 14 May 2009 - Accepted: 15 May 2009 - Published: 3 June 2009

\begin{abstract}
A simulation model based on satellite observations of monthly vegetation cover from the Moderate Resolution Imaging Spectroradiometer (MODIS) was used to estimate monthly carbon fluxes in terrestrial ecosystems of Brazilian Amazon and Cerrado regions over the period 2000-2004. Net ecosystem production (NEP) flux for atmospheric $\mathrm{CO}_{2}$ in the region for these years was estimated. Consistently high carbon sink fluxes in terrestrial ecosystems on a yearly basis were found in the western portions of the states of Acre and Rondônia and the northern portions of the state of Pará. These areas were not significantly impacted by the 2002-2003 El Niño event in terms of net annual carbon gains. Areas of the region that show periodically high carbon source fluxes from terrestrial ecosystems to the atmosphere on yearly basis were found throughout the state of Maranhão and the southern portions of the state of Amazonas. As demonstrated though tower site comparisons, NEP modeled with monthly MODIS Enhanced Vegetation Index (EVI) inputs closely resembles the measured seasonal carbon fluxes at the LBA Tapajos tower site. Modeling results suggest that the capacity for use of MODIS Enhanced Vegetation Index (EVI) data to predict seasonal uptake rates of $\mathrm{CO}_{2}$ in Amazon forests and Cerrado woodlands is strong.
\end{abstract}

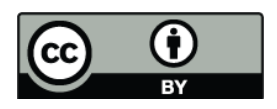

Correspondence to: C. Potter (chris.potter@nasa.gov)

\section{Introduction}

Carbon dioxide $\left(\mathrm{CO}_{2}\right)$ is a major contributor to the planetary greenhouse effect and potential climate change. Altered cycles of carbon, water, energy, and nutrients resulting from the changes in Amazonian vegetation cover are expected to have climatic and environmental consequences at local, regional, and global scales. The Large Scale Biosphere-Atmosphere Experiment in Amazonia (LBA) is an international research initiative led by Brazil whose main science objectives include developing methods to quantify, understand, and model the processes controlling carbon cycling in the Amazon region and in the contiguous Cerrado region.

Several previous studies of ecosystem modeling, namely Kindermann et al. (1996), Potter et al. (1998), Tian et al. (1998), Prentice and Lloyd (1998), Asner et al (2000), Houghton et al. (2000), Potter et al. (2001), and Foley et al. (2002), have examined how variations in climate affect the carbon balance of the Amazon basin. Most of these models suggested that the net annual flux of carbon by the basin is significantly correlated to El Niño Southern Oscillation (ENSO) events. The Amazon basin was predicted to be a significant carbon sink during La Niña events, and a carbon source during El Niño events. Moreover, these modeling studies published before most data from the LBA project was generated concluded that major variations in the regional carbon balance are related chiefly to changes in precipitation. Generally, the average El Niño event has been drier than normal, and the average La Niña period wetter in northern Amazonia. In southern Amazonia, both recent El Niño and La Niña periods have been drier than neutral conditions.

Published by Copernicus Publications on behalf of the European Geosciences Union. 
The launch of NASA's Terra satellite platform in December 1999 with the Moderate Resolution Imaging Spectroradiometer (MODIS) instrument on-board initiated a new era in remote sensing of the Earth system with promising implications for carbon cycle research. Direct input of satellite vegetation index "greenness" data from the MODIS sensor into ecosystem simulation models is now used to estimate spatial variability in monthly net primary production (NPP), biomass accumulation, and litter fall inputs to soil carbon pools. Global NPP of vegetation can be predicted using the relationship between leaf reflectance properties and the absorption of photosynthetically active radiation (PAR), assuming that net conversion efficiencies of PAR to plant carbon can be approximated for different ecosystems or are nearly constant across all ecosystems (Running and Nemani, 1988; Goetz and Prince, 1998).

Operational MODIS algorithms generate the Enhanced Vegetation Index (EVI) (Huete et al., 2002) as global image coverages from 2000-present. EVI represents an optimized vegetation index, whereby the vegetation index isolines in red and near infra-red spectral bands are designed to approximate vegetation biophysical isolines derived from canopy radiative transfer theory and/or measured biophysical-optical relationships. EVI was developed to optimize the greenness signal, or area-averaged canopy photosynthetic capacity, with improved sensitivity in high biomass regions. The EVI has been found useful in estimating absorbed PAR related to chlorophyll contents in vegetated canopies (Zhang et al., 2005), and has been shown to be highly correlated with processes that depend on absorbed light, such as gross primary productivity (GPP) (Xiao et al., 2004; Rahman, 2005; Huete et al., 2006).

In this study, we present the results of CASA (Carnegie Ames Stanford Approach) model predictions of terrestrial ecosystem fluxes using 2000-2004 MODIS EVI inputs at 8$\mathrm{km}$ spatial resolution. This is the first LBA regional modeling study to infer variability in region-wide carbon fluxes for the Brazilian Amazon and Cerrado (savanna) ecosystems at such a detailed spatial resolution from NASA satellite data. Our CASA model (Potter et al., 1993, 1999, and 2003) has been designed to uniquely estimate monthly patterns in carbon fixation, plant biomass increments, nutrient allocation, litter fall, soil carbon, $\mathrm{CO}_{2}$ exchange, and soil nutrient mineralization. We also validate the model for the first time using LBA tower flux estimates for net ecosystem exchange of $\mathrm{CO}_{2}$ in Amazon forests.

\section{Modeling methods and data sets}

As documented in Potter (1999), the monthly NPP flux, defined as net fixation of $\mathrm{CO}_{2}$ by vegetation, is computed in NASA-CASA on the basis of light-use efficiency (Monteith, 1972). Monthly production of plant biomass is estimated as a product of time-varying surface solar irradiance, $S_{r}$, and EVI from the MODIS satellite, times a constant light utilization efficiency term $\left(e_{\max }\right)$ that is modified by time-varying stress scalar terms for temperature $(T)$ and moisture $(W)$ effects (Eq. 1).

$\mathrm{NPP}=S_{r} \mathrm{EVI} e_{\max } T W$

The $e_{\max }$ term is set uniformly at $0.39 \mathrm{~g} \mathrm{C} \mathrm{MJ}^{-1} \mathrm{PAR}$, a value that derives from calibration of predicted annual NPP to previous field estimates (Potter et al., 1993). This model calibration has been validated globally by comparing predicted annual NPP to more than 1900 field measurements of NPP (Zheng et al., 2003; Potter et al., 2007). The model uses the same $e_{\max }$ value for all vegetation types in the Amazon, but allows predicted light use efficiency to be regulated by monthly climate variations that vary across the region. Future fertilization effects from atmospheric $\mathrm{CO}_{2}$ concentrations were considered to be inconsequential in our model, because the NPP algorithms in CASA are calibrated to current global estimates and we do not run the model into future years with elevated $\mathrm{CO}_{2}$ fluxes.

Interannual NPP fluxes from the CASA model have been reported (Behrenfeld et al., 2001; Potter et al., 2001) and validated against multi-year estimates of NPP from field stations and tree rings (Malmström et al., 1997). Our NASA-CASA model has been validated against field-based measurements of NEP fluxes and carbon pool sizes at multiple boreal forest sites (Potter et al., 2001; Amthor et al., 2001; Hicke et al., 2002) and against atmospheric inverse model estimates of global NEP (Potter et al., 2003). The CASA model was shown to accurately simulate evapotranspiration fluxes in the Amazon region (Potter et al., 1998,2001).

The $T$ stress scalar is computed with reference to derivation of optimal temperatures $\left(T_{\mathrm{opt}}\right)$ for plant production. The $T_{\mathrm{opt}}$ setting will vary by latitude and longitude, ranging from near $0^{\circ} \mathrm{C}$ in the Arctic to the middle thirties ${ }^{\circ} \mathrm{C}$, in low latitude deserts. The $W$ stress scalar is estimated from monthly water deficits, based on a comparison of moisture supply (precipitation and stored soil water) to potential evapotranspiration (PET) demand using the method of Priestly and Taylor (1972). Latent heat fluxes were predicted as estimated evapotranspiration (EET) amounts, which was determined the lower value in a comparison of monthly PET and precipitation plus stored soil water volumes.

The Moderate Resolution Imaging Spectroradiometer (MODIS) 1-km land cover map (Friedl et al., 2002) aggregated to $8-\mathrm{km}$ pixel resolution was used to specify the predominant land cover class for the $W$ term in each pixel as either forest, savanna (Cerrado) crop, pasture, or other classes (i.e., water or urban area). Monthly mean surface air temperature and precipitation grids for model simulations over the years 2000-2004 came from NCEP reanalysis products (Kistler et al., 2001). Monthly mean inputs of solar radiation flux to the model were derived from top of the atmosphere shortwave radiation budget products of Laszlo et al. (1997 and 2006). 
Evapotranspiration is connected to water content in the soil profile layers (Fig. 1), as estimated using the NASACASA algorithms as described by Potter (1999). The soil model design includes three-layer $\left(M_{1}-M_{3}\right)$ heat and moisture content computations: surface organic matter, topsoil $(0.3 \mathrm{~m})$, and subsoil to rooting depth (1 to $10 \mathrm{~m})$. These layers can differ in soil texture, moisture holding capacity, and carbon-nitrogen dynamics. Water balance in the soil is modeled as the difference between precipitation or volumetric percolation inputs, monthly estimates of PET, and the drainage output for each layer. Inputs from rainfall can recharge the soil layers to field capacity. Excess water percolates through to lower layers and may eventually leave the system as seepage and runoff.

Based on plant production as the primary carbon and nitrogen cycling source, the NASA-CASA model is designed to couple daily and seasonal patterns in soil nutrient mineralization and soil heterotropic respiration $\left(R_{h}\right)$ of $\mathrm{CO}_{2}$ from soils worldwide. Net ecosystem production (NEP) can be computed as NPP minus $R_{h}$ fluxes, excluding the effects of small-scale fires and other localized disturbances or vegetation regrowth patterns on carbon fluxes. The NASA-CASA soil model uses a set of compartmentalized difference equations with a structure comparable to the CENTURY ecosystem model (Parton et al., 1992). First-order decay equations simulate exchanges of decomposing plant residue (metabolic and structural fractions) at the soil surface. The model also simulates surface soil organic matter (SOM) fractions that presumably vary in age and chemical composition. Turnover of active (microbial biomass and labile substrates), slow (chemically protected), and passive (physically protected) fractions of the SOM are represented. Along with moisture availability and litter quality, the predicted soil temperature in the $M_{1}$ layer controls SOM decomposition.

The NASA-CASA soil carbon pools were initialized to represent storage and flux conditions in near steady state (i.e., an annual NEP flux less than $0.5 \%$ of annual NPP flux) with respect to mean land surface climate recorded for the period 1979-1981 (New et al., 2000). This initialization protocol was found to be necessary to eliminate any notable discontinuities in predicted NEP fluxes during the transition to our model simulation years of interest prior to MODIS EVI availability, which were run on a monthly time step starting January 1982 to December 2000. Initializing to near steady state does not, however, address the issue that some ecosystems are not in equilibrium with respect to net annual carbon fluxes, especially when they are recovering from past disturbances. For instance, it is openly acknowledged that the NASA-CASA modeling approach using 8-km satellite data inputs cannot capture all the carbon sink effects of forest regrowth from recent wood harvest activities (Turner, 2005), although impacts of major wildfires are detectable (Potter et al., 2005). Higher resolution (250-m) MODIS EVI data sets are currently in the evaluation phase for use in NASA-CASA model runs for deforested and regrowth areas.
Whereas previous versions of the NASA-CASA model (Potter et al., 1993, 1999) used a normalized difference vegetation index (NDVI) to estimate FPAR, the current model version instead has been recalibrated to use MODIS EVI datasets as direct inputs to Eq.(1) above. In long-term (19822004) simulations, continuity between AVHRR and MODIS sensor data for inputs to NASA-CASA is an issue that must be addressed by recalibration of annual NPP results post 2000. NASA-CASA model predictions with 2001 monthly MODIS EVI inputs have been adjusted using the same set of field measurements of NPP (Olson et al., 1997; Potter et al., 2003, 2007; Zheng et al., 2003). To best match the predictions with previously measured NPP estimates at the global scale $\left(R^{2}=0.91\right)$, the model $e_{\max }$ term for 2001 MODIS EVI inputs was reset to $0.55 \mathrm{~g} \mathrm{C} \mathrm{MJ}^{-1} \mathrm{PAR}$.

\section{Evaluation of net carbon flux results at tower sites}

Measurements of net ecosystem carbon exchange from tower studies of eddy correlation can be used with confidence for the purpose of carbon model evaluation, but only after independent confirmation research can show that a given tower flux time series can in fact yield consistently high quality measurements of NEP. Tower flux data from Tapajós National Forest (TNF) sites near Santarém, Pará have been validated using radon as a tracer (Martens et al., 2004), which indicated that eddy flux carbon balance were realistic there.

The TNF tower site is in the east-central Brazilian Amazon $\left(2^{\circ} 54^{\prime} \mathrm{S}, 54^{\circ} 57^{\prime} \mathrm{W}\right)$. The region receives an average annual rainfall of about $2000 \mathrm{~mm}$, varying between 600 and $3000 \mathrm{~mm}$ annually, and suffers severe drought stress during ENSO episodes. Soils are deeply weathered Oxisols (Haplustox), with no concretions or impeding layers in the upper $12 \mathrm{~m}$. The water table is $100 \mathrm{~m}$ below the soil surface.

Comparison of NASA-CASA predicted net ecosystem exchange (NEE, which is merely the negative transform of monthly NEP flux) to measurements at the TNF site (Hutyra et al., 2007) showed a close month-to-month match $\left(R^{2}=0.57\right)$ between the two flux estimates over the threeyear period, 2002-2004 (Fig. 2). This comparison assumed a one-month lag correction in the NASA-CASA predicted NEE flux, due mainly to the rapid response of heterotropic respiration $\left(R_{h}\right)$ flux of carbon to changes in soil water that the monthly time step in NASA-CASA cannot update on a shorter time interval. Nonetheless, the NASA-CASA model predictions closely track the seasonality and magnitude of tower measurements of NEE, with net source fluxes (positive NEE) during the wet season periods and rapid transition to net sink fluxes (negative NEE) during the dry season periods of each year. By separating the NASA-CASA predicted NEE flux into its component (NPP and $R_{h}$ ) fluxes, (Fig. 3), the opposite seasonality of forest NPP and soil $R_{h}$ fluxes of $\mathrm{CO}_{2}$ can be easily discerned. Predicted soil $R_{h}$ fluxes were nearly as variable as predicted NPP fluxes over the course of 
(a) Soil Moisture Balance and Plant Functional Types (b) Ecosystem Production

Nutrient Mineralization

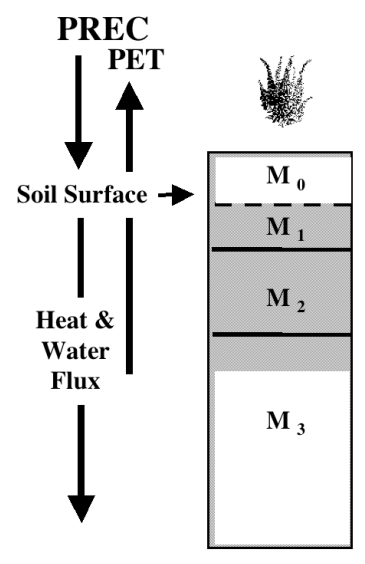

Grass/Crop

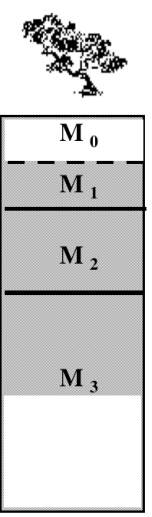

Shrub

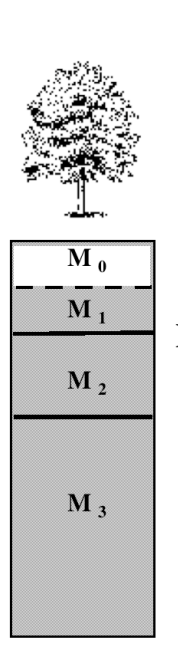

Tree

Fig. 1. Schematic representation of components in the NASA-CASA model. The soil profile component (a) is layered with depth into a surface ponded layer $\left(M_{0}\right)$, a surface organic layer $\left(M_{1}\right)$, a surface organic-mineral layer $\left(M_{2}\right)$, and a subsurface mineral layer $\left(M_{3}\right)$, showing typical levels of soil water content (shaded) in three general vegetation types (DeFries et al., 1995). The production and decomposition component (b) shows separate pools for carbon cycling among pools of leaf litter, root litter, woody detritus, microbes, and soil organic matter, with dependence on litter quality $(q)$.

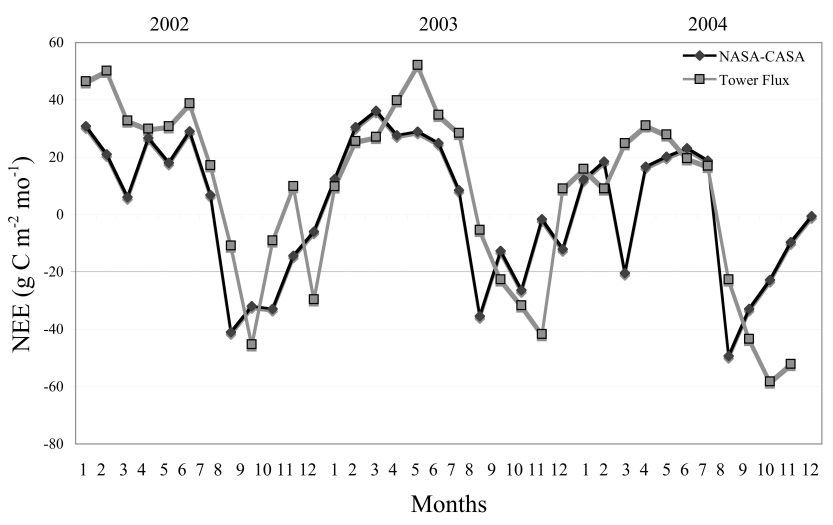

Fig. 2. Comparison of the 8-km resolution NASA-CASA predicted NEE versus measured monthly NEE from the Tapajós National Forest (TNF) tower flux site near Santarém, Pará.

an entire year. $R_{h}$ fluxes were highest in the wet season and declined rapidly at the same time that dry season NPP fluxes increased rapidly.

Other than the TNF tower flux data sets, we are not aware of similarly comprehensive field validation work completed for other Amazon forest tower sites. Furthermore, measurements at the ZF2 Manaus tower site (which used a multiple regression analysis to identify times when nighttime measurements are reliable) suggested that only rarely could the

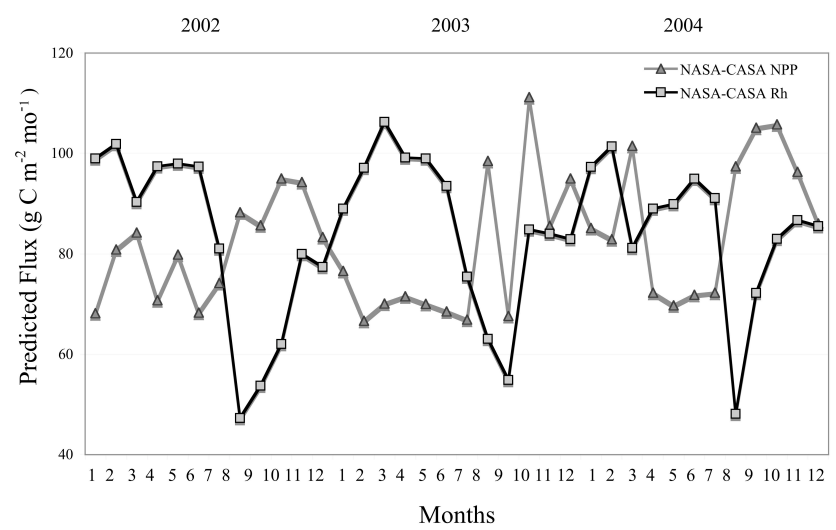

Fig. 3. Monthly patterns of the NASA-CASA predicted NPP and $R_{h}$ fluxes at the Tapajós National Forest (TNF) tower flux site.

eddy flux carbon balance be used with confidence for daily carbon balance purposes. This is due to low atmospheric turbulence. Chambers et al. (2004) were able to identify only about $100 \mathrm{~h}$ out of over 4000 measurements of the nighttime eddy flux collected at this tower site to develop a net carbon budget, which would not be sufficient for long-term seasonal evaluation tests of ecosystem carbon models such as NASACASA. 
Nevertheless, Chambers et al. (2004) directly measured respiration rates from live leaf, live wood, and forest soil surfaces to derive an indirect ecosystem NPP flux estimate of $900 \mathrm{~g} \mathrm{C} \mathrm{m}^{-2} \mathrm{yr}^{-1}$, and further partitioned belowground respiration fluxes for an annual $R_{h}$ estimation of $850 \mathrm{~g} \mathrm{C} \mathrm{m}^{-2} \mathrm{yr}^{-1}$ (and an NEP sink flux estimate of $+50 \mathrm{~g} \mathrm{C} \mathrm{m}^{-2} \mathrm{yr}^{-1}$ ) at the ZF2 Manaus tower site for the period 1999-2000. In comparison, our NASA-CASA predictions for annual NPP flux at this site ranged from 839 to $867 \mathrm{~g} \mathrm{C} \mathrm{m}^{-2} \mathrm{yr}^{-1}$ for the period 2001-2004 with a mean annual NPP flux of $857 \mathrm{~g} \mathrm{C} \mathrm{m}^{-2} \mathrm{yr}^{-1}$, and mean annual $R_{h}$ flux of $846 \mathrm{~g} \mathrm{C} \mathrm{m}^{-2} \mathrm{yr}^{-1}$, for a NEP flux estimate of $+11 \mathrm{~g} \mathrm{C} \mathrm{m}^{-2} \mathrm{yr}^{-1}$ at the ZF2 Manaus site. Taking into consideration the high levels of topographic and soil variations affecting forest carbon fluxes over this area of the central Amazon, the apparent difference of less than $1 \%$ between measured and our modeled annual $R_{h}$ fluxes at the Manaus site is an important confirmation of the NASA-CASA performance at this additional LBA study location.

\section{Regional carbon flux results}

Annually summed NPP fluxes for the Legal Amazon region of Brazil decreased gradually over the period of 20002004, from 4.34 $\mathrm{PgC} \mathrm{Cr}^{-1}\left(1 \mathrm{Pg}=10^{15} \mathrm{~g}\right)$ in 2001 to a low of $4.25 \mathrm{Pg} \mathrm{Cyr}^{-1}$ in 2002 , and then again to $4.26 \mathrm{Pg} \mathrm{Cyr}^{-1}$ in 2004. (Fig. 4a). The smoothed trend in monthly NPP rates over the region, which were typically predicted by the model to peak during the period of October to January, declined steadily over the period from 2001 to early 2003, and then recovered slowly over the subsequent two years for the region.

Annually summed NEP fluxes for the Legal Amazon region varied from year to year over the period of 20002004, from a relatively low $\mathrm{CO}_{2}$ emission source of $-0.07 \mathrm{PgC} \mathrm{yr}^{-1} \mathrm{C}$ in 2000 to a higher of $\mathrm{CO}_{2}$ emission source of $-0.13 \mathrm{Pg} \mathrm{C} \mathrm{yr}^{-1}$ in 2002 (Fig. 4b). The modeled NEP fluxes were controlled strongly by monthly predicted $R_{h}$ fluxes of $\mathrm{CO}_{2}$ from soil microbial activity, in which case $R_{h}$ accounted for more that $32 \%$ of the variation in the predicted NEP sink fluxes region-wide (based on the correlation coefficient $r$, significant at a level of $p<0.01)$. Monthly NEP predictions were not highly correlated $(r=0.2$; not significant at $p<0.1)$ with predicted NPP fluxes on a month-to-month basis.

Geographic patterns in annually summed NPP and NEP fluxes confirm that the year 2002 stood out from the other years 2000-2004 with lower ecosystem productivity and relatively large carbon source fluxes across the region (Fig. 5). This year-to-year contrast can be most readily observed in the north eastern portion of the Brazilian Amazon region, specifically along the entire Tocantins River basin as far south as the city of Marabá, along the Tapajós River basin located south of the Amazon River main stem between

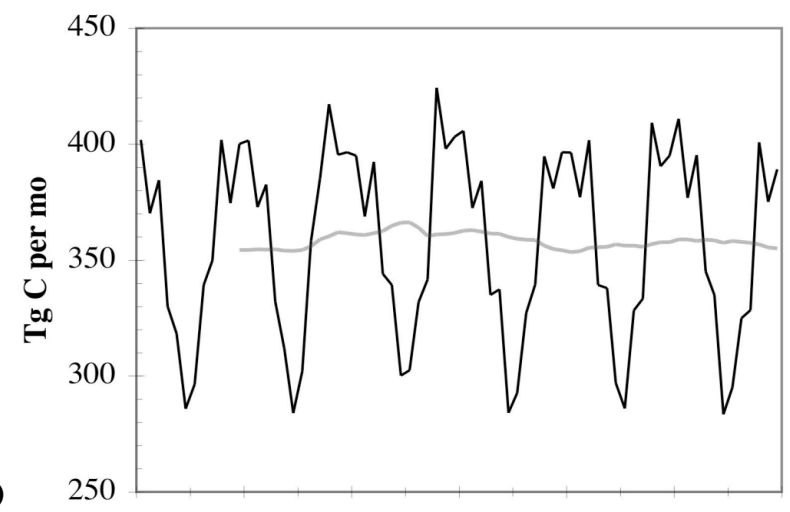

(a)

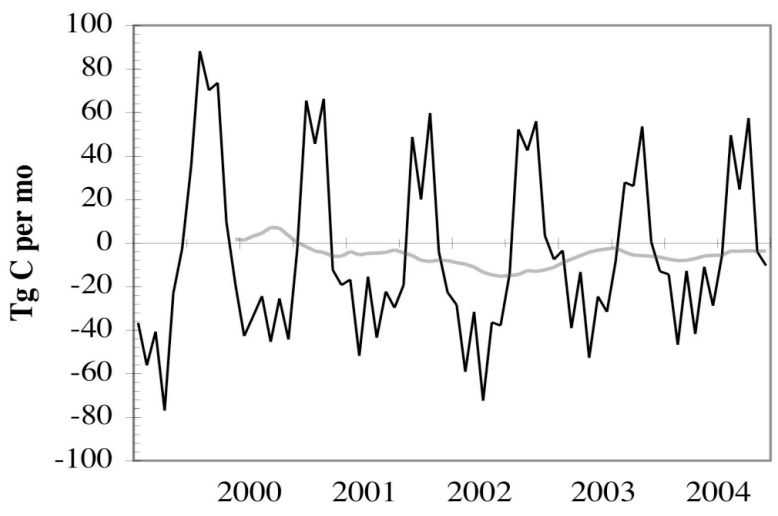

Fig. 4. (a) Net Primary Production (NPP) in ecosystems of the Brazilian Amazon region from 2000 to 2004. Thin line is the monthly predicted NPP; thick line is the 12-month running average NPP. (b) Net Ecosystem Production (NEP) of the Brazilian Amazon region from 2000 to 2004 . Thin line is monthly predicted NEP; thick line is the 12-month running average NEP.

longitudes $57^{\circ}$ and $54^{\circ} \mathrm{W}$, and also in the zones located just north and as far west as Lago Badajós from the city of Manaus, mainly between longitudes $64^{\circ}$ and $60^{\circ} \mathrm{W}$. Due in part to a $5-15 \%$ decline in annual predicted NPP, predicted annual NEP for these specific Amazon forest zones typically switched from a net sink flux on the order of +20 to $+90 \mathrm{~g} \mathrm{C} \mathrm{m}^{-2} \mathrm{yr}^{-1}$ during 2001 and 2003 to net source flux on the order of -30 to $-75 \mathrm{~g} \mathrm{C} \mathrm{m}^{-2} \mathrm{yr}^{-1}$ during 2002.

According to the climate data inputs to these NASACASA runs, total precipitation across the Legal Amazon states of Brazil was about 3\% above the regional five-year (2000-2004) mean in 2000 and 2001 and was about $6 \%$ below the regional five-year mean in 2002. Zeng et al. (2008) analyzed the regional impacts of drought in the Amazon culminating in 2005 and attributed the causes to the combination of 2002-2003 El Niño event and another dry period in 2005 that was coupled to warm subtropical North Atlantic Ocean conditions. According to standardized precipitation index (SPI) values derived from satellite rainfall data (Janowiak and Xie, 1999), the 2002-03 El Niño event was as strong 


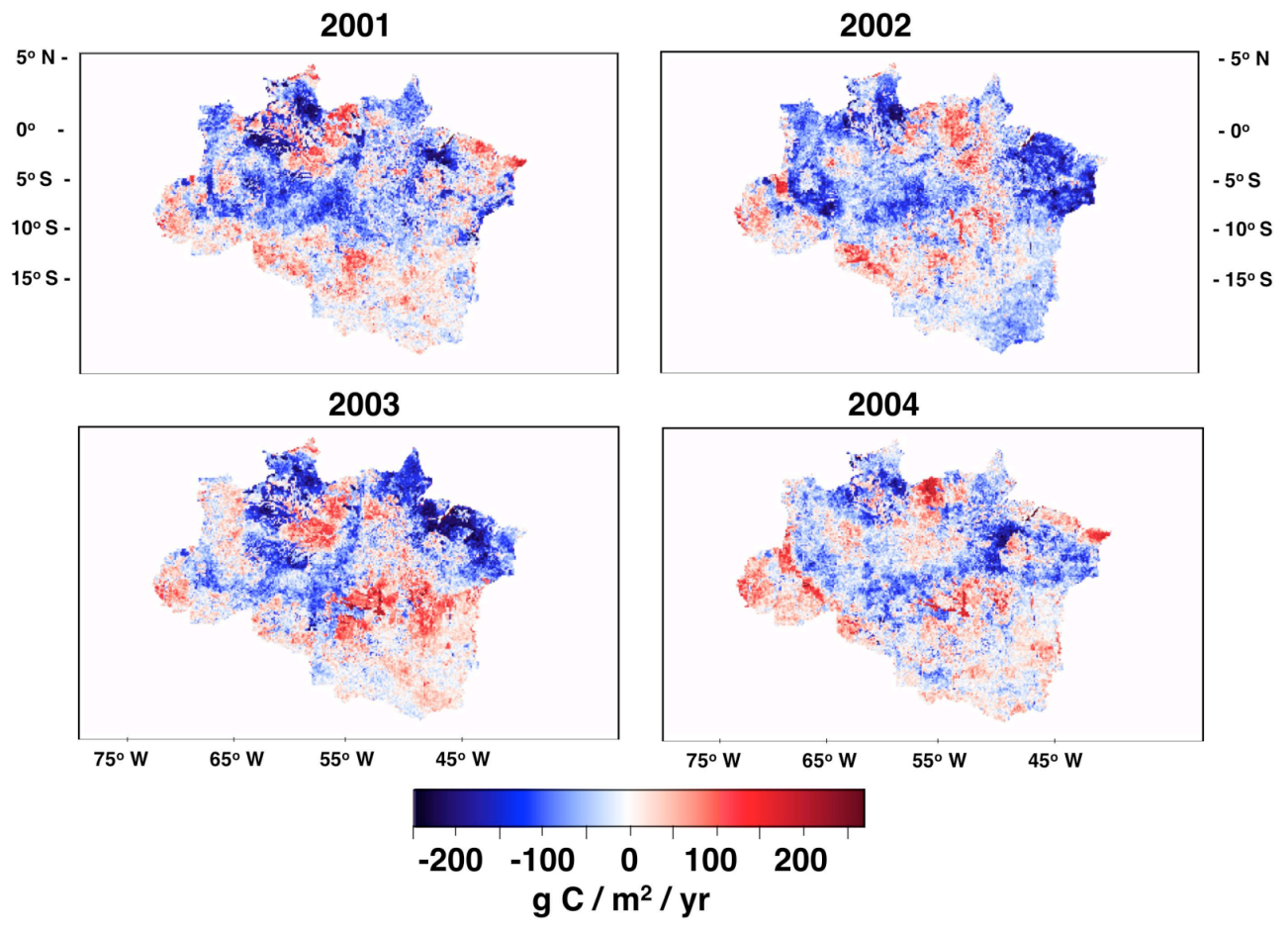

Fig. 5. Predicted annual NEP fluxes from the NASA-CASA model from 2001 to 2004 over the Brazilian Amazon region.

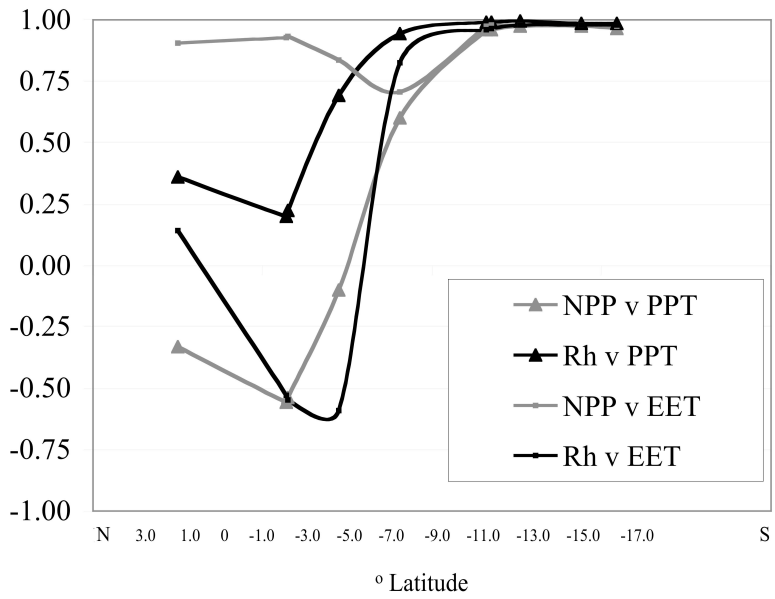

Fig. 6. Correlation coefficients ( $r$ values) for CASA model monthly $\mathrm{NPP}$ and $\mathrm{Rh}$ fluxes of $\mathrm{CO}_{2}$ versus monthly precipitation amounts (PPT) or predicted EET fluxes of water over the period 2001-2004. Lines are based on ten randomly selected latitude zones, starting from north of the Equator (positive latitude values) to south (negative latitude values) of the Equator. Absolute values of $r>0.25$ are significant at the level of $p<0.05$ ( $n=48$ months).

as the 1997-98 El Niño event across the Amazon, and contributed to near record-low stream flows and enhanced fire frequency by 2006 .
The NASA-CASA model predictions for the Cerrado woodland zones represented in the states of Mato Grosso and Goiás were also impacted by the 2002-2003 El Niño event with lower ecosystem productivity and relatively large carbon source fluxes (Fig. 5). Predicted annual NEP for these specific Cerrado zones typically switched from a net sink flux on the order of $+30 \mathrm{~g} \mathrm{C} \mathrm{m}^{-2} \mathrm{yr}^{-1}$ during 2001 and 2003 to net source flux on the order of $-25 \mathrm{~g} \mathrm{C} \mathrm{m}^{-2} \mathrm{yr}^{-1}$ during 2002.

A unique contribution of the CASA model has been detailed spatial mapping of interannual variation in ecosystem carbon fluxes (Potter et al., 2002). To further explore potential climate controls over Amazon carbon source $\left(R_{h}\right)$ and sink (NPP) fluxes, zonal correlations between aggregated CASA $\mathrm{CO}_{2}$ fluxes and monthly precipitation amounts (PPT) or predicted EET fluxes of water were computed over the period 2001-2004. Results in Fig. 6 revealed that interannual variations in both precipitation and latent heat fluxes (as represented in EET) strongly controlled the predicted carbon source and sink fluxes in zones south of $7^{\circ} \mathrm{S}$ latitude, whereas latent heat fluxes alone were far more important controllers of NPP than were monthly precipitation amounts in zones north of $7^{\circ} \mathrm{S}$ latitude. On the basis of these results, we hypothesize that rainfall is rarely limiting to net ecosystem carbon in the Amazon forest zones north of about $7^{\circ} \mathrm{S}$ latitude, and that seasonal variation in solar irradiance is a more important controller of annual NPP levels in these areas. 


\section{Discussion}

Previous ecosystem modeling studies such as those of Tian et al. (1998) and Foley et al. (2002) have implied that major variations in the regional carbon balance of the Amazon are related chiefly to ENSO precipitation patterns. Our current study results, combined with previous CASA findings from Potter et al. (2004) are consistent with these previous findings, mainly for the northern portion of the Amazon region. Our prior model analysis over the period 1982-1998 suggested that temperature effects of ENSO cycles can also have notable impacts on Amazon carbon fluxes over decadelong time periods. Specifically, model anomalies in NPP and NEP over large areas of the Amazon region east of $60^{\circ} \mathrm{W}$ longitude were strongly correlated with the Southern Oscillation Index (SOI). To explain NEP anomalies, reasonably strong temperature correlations with SOI were even more widespread regionally than were strong correlations of precipitation with SOI.

It is worth noting that NASA-CASA has the potential to generate results that are very different than other models such those described by Tian et al. (1998) and Foley et al. (2002), largely because NASA-CASA relies on monthly satellite data as an input. The MODIS and AHVRR sensors generate observations of the actual land vegetation dynamics, which are lacking in the other cited models, and which can be sensitive to variability on temperature as well as precipitation.

At the regional scale, the CASA model of Potter et al. (2004) estimated NPP for the total Amazon region (beyond Brazil) to vary between 8.7 (in 1983) and $9.8 \mathrm{PgC}$ (in 1997) $\mathrm{yr}^{-1}$, with a seasonal anomaly range of about $0.1 \mathrm{Pg} \mathrm{C}$ month $^{-1}$. This study also inferred an increase in NPP for the region over the 17-year time period of 19821998. The predicted NEP flux for atmospheric $\mathrm{CO}_{2}$ over the region varied between an annual source (to the atmosphere) of $0.17 \mathrm{PgC} \mathrm{yr}^{-1}$ in 1983 to a sink (from the atmosphere) of $0.64 \mathrm{PgC} \mathrm{yr}^{-1}$ in 1989 , with a seasonal anomaly range of up to $0.1 \mathrm{PgC}$ month $^{-1}$. The NPP and NEP predictions from our new MODIS-era study of the Brazilian Amazon states fit well within these previous total flux ranges, and have the distinct advantage of matching tower fluxes closely. Due in part to improved sensitivities to declines in annual predicted primary production detected uniquely by the MODIS sensor data, predicted annual NEP for specific Amazon forest zones can be mapped out as switching from a net sink flux to a net source during ENSO cycles, a capability never before available for assessing long-term ecosystem carbon balance across this remote region. Our newest CASA results include carbon fluxes for the Cerrado region as well, which deserves much greater study in high-resolution (1-km or finer) model runs that are being designed next for CASA to include many different crop systems from converted savanna ecosystems.

Inclusion of deforestation sources of $\mathrm{CO}_{2}$ emission in tropical zones is a crucial next step in developing a full carbon balance for the region. Previously, VanderWerf et al. (2003) used the CASA model with inputs from satellite observations of global rainfall from the NASA Tropical Rainfall Monitoring Mission (TRMM) to account for the effects of fire on regional carbon stocks and ecosystem carbon fluxes. Annual carbon emissions from fires in the Legal Amazon were estimate to range from 0.2 to $0.5 \mathrm{PgC} \mathrm{yr}^{-1}$. In comparison, Potter et al. (2002) used the CASA model production and biomass predictions together with Landsatderived mapping of burned areas for the Legal Amazon states to estimate total ecosystem source to range from 0.2 to $1.2 \mathrm{Pg} \mathrm{Cyr}^{-1}$ for the period 1992-1993. The CARbon and Land-Use Change (CARLUC) model estimates the net flux caused by deforestation and forest re-growth (Hirsch et al., 2004). CARLUC predicted that the net flux to the atmosphere from the Legal Amazon area during the period from 1970 to 1998 reached a maximum of $0.35 \mathrm{Pg} \mathrm{Cyr}^{-1}$ in 1990 , with a cumulative release of $7 \mathrm{PgC}$. The net flux is higher than predicted by an earlier study (Houghton et al., 2000) by a total of $1 \mathrm{Pg} \mathrm{C}$ over the period 1989-1998, mainly because CARLUC predicts relatively high mature forest carbon storage compared with the datasets used in earlier studies.

\section{Conclusions}

The results of NASA-CASA model simulations of NPP and NEP across the Brazilian Amazon and into the Cerrado regions from 2001-2004 have several noteworthy implications for LBA assessment studies:

- Areas of the region that show consistently high carbon sink fluxes in terrestrial ecosystems on a yearly basis are the western portions of the states of Acre and Rondônia and the northern portions of the state of Pará. These areas were not significantly impacted by the 2002-2003 El Niño event in terms of net annual carbon gains.

- Areas of the region that show periodically high carbon source fluxes from terrestrial ecosystems to the atmosphere on yearly basis are throughout the state of Maranhão and the southern portions of the state of Amazonas. These areas were predicted as being strongly affected by the 2002-2003 El Niño event in terms of reducing net annual carbon gains.

- Cerrado region (woodland savanna formations) showed behavior of NEP on yearly basis similar to the southern part of the Amazon but fluxes were approximately one third of those measured for the Amazon region.

We note in closing that an advantage of combining ecosystem modeling with satellite observations for vegetation cover properties is to uniquely enhance the spatial resolution of source and sink patterns for $\mathrm{CO}_{2}$ in the terrestrial biosphere. Using MODIS land products, carbon modelers have begun 
to identify numerous relatively small-scale patterns throughout the world where terrestrial carbon fluxes have varied in recent years between net annual sources and sinks. Predictions of NEP for these areas of high interannual variability will require further uncertainty analysis of carbon model estimates, with a focus on both flux algorithm mechanisms and potential scaling errors to the regional level.

Acknowledgements. This work was supported by grants from NASA LBA-ECO program and the NASA Earth Observing System (EOS) Interdisciplinary Science program. We thank Steven Wofsy and Lucy Hutyra for advice on the use of carbon flux measurement data.

Edited by: G. Wohlfahrt

\section{References}

Amthor, J. S., Chen, J. M., Clein, J. S., Frolking, S. E., Goulden, M. L., Grant, R. F., Kimball, J. S., King, A. W., McGuire, A. D., Nikolov, N. T., Potter, C. S., Wang, S., and Wofsy, S. C.: Boreal forest $\mathrm{CO}_{2}$ exchange and evapotranspiration predicted by nine ecosystem process models: Inter-model comparisons and relations to field measurements, J. Geophys. Res., 106, 33,62333,648, 2001.

Asner, G. P., Townsend, A. R., and Braswell, B. H.: Satellite observation of El Nino effects on Amazon forest phenology and productivity, Geophys. Res. Lett., 27, 981-984, 2000.

Behrenfeld, M. J., Randerson, J. T., McClain, C. R., Feldma, G. C., Los, S. Q., Tucker, C. I., Falkowski, P. G., Field, C. B., Frouin, R., Esaias, W. E., Kolber, D. D., and Pollack, N. H.: Biospheric primary production during an ENSO transition, Science, 291, 2594-2597, 2001.

Chambers, J. Q., Tribuzy, E. S., Toledo, L. C., Crispim, B. F., Higuchi, N., dos Santos, J., Araujo, A. C., Kruijt, B., Nobre, A. D., and Trumbore, S. E.: Respiration from a tropical forest ecosystem: Partitioning of sources and low carbon use efficiency, Ecol. Appl., 14, S72-S88, 2004.

DeFries, R., Hansen, M., and Townshend, J.: Global discrimination of land cover types from metrics derived from AVHRR Pathfinder data, Remote Sens. Environ., 54, 209-222, 1995.

Foley, J. A., Botta, A., Coe, M. T., and Costa, M. H.: The El Nino/Southern Oscillation and the climate, ecosystems and rivers of Amazonia, Global Biogeochem. Cy., 16(4), 1132, 10.1029/2002GB001872, 2002.

Friedl, M. A., McIver, D. K., Hodges, J. C. F., Zhang, X. Y., Muchoney, D., Strahler, A. H., Woodcock, C. E., Gopal, S., Schneide, A., Cooper, A., Baccini, A., Gao, F., and Schaaf, C.: Global land cover mapping from MODIS: algorithms and early results, Remote Sens. Environ., 83, 287-302, 2002.

Goetz, S. J. and Prince, S. D.: Variability in light utilization and net primary production in boreal forest stands, Can. J. Forest Res., 28, 375-389, 1998.

Hicke, J. A., Asner, G. P., Randerson, J. T., Tucker, C. J., Los, S. O., Birdsey, R., Jenkins, J. C., Field, C. B., and Holland, E. A.: Satellite-derived increases in net primary productivity across North America, 1982-1998, Geophys. Res. Lett., 29(10), 1427, doi:10.1029/2001GL013578, 2002.
Hirsch, A. I., Little, W., Houghton, R. A., Scott, N. A., and White, J. D.: The net carbon flux due to deforestation and forest re-growth in the Brazilian Amazon: Analysis using a process-based model, Glob. Change Biol., 10, 908-924, 2004.

Houghton, R. A., Skole, D. L., Nobre, C. A., Hackler, J. L., Lawrence, K. T., and Chomentowski, W. H.: Annual fluxes of carbon from deforestation and regrowth in the Brazilian Amazon, Nature, 403, 301-304, 2000.

Huete, A., Didan, K., Miura, T., Rodriguez, E. P., Gao, X., and Ferreira, L. G.: Overview of the radiometric and biophysical performance of the MODIS vegetation indices, Remote Sens. Environ., 83, 195-213, 2002.

Huete, A. R., Didan, K., Shimabukuro, Y. E., Ratana, P., Saleska, S. R., Hutyra, L. R., Fitzjarrald, D., Yang, W., Nemani, R. R., and Myneni, R.: Amazon rainforests green-up with sunlight in the dry season, Geophys. Res. Lett., 33, L06405, doi:10.1029/2005GL025583, 2006.

Hutyra L. R., Munger, J. W., Saleska, S. R., Gottlieb, E., Daube, B. C., Dunn, A. L., Amaral, D. F., de Camargo, P. B., and Wofsy, S. C.: Seasonal controls on the exchange of carbon and water in an Amazonian rain forest, J. Geophys. Res., 112, G03008, doi:10.1029/2006JG000365, 2007.

Janowiak, J. E. and Xie, P.: CAMS-OPI: a global satellite-rain gauge merged product for real-time precipitation monitoring applications, J. Climate, 12 3335-42, 1999.

Kindermann, J., Wurth, G., Kohlmaier, G. H., and Badeck, F. W.: Interannual variation of carbon exchange fluxes in terrestrial ecosystems, Global Biogeochemical Cy., 10, 737-755, 1996.

Kistler, R., Kalnay, E., Collins, W., Saha, S., White, G., Woollen, J., Chelliah, M., Ebisuzaki, W., Kanamitsu, M., Kousky, V., van den Dool, H., Jenne, R., and Fiorino, M.: The NCEP-NCAR 50-Year Reanalysis: Monthly Means CD-ROM and Documentation, B. Am. Meteorol. Soc., 82, 247-268, 2001.

Laszlo, I., Pinker, R. T., and Whitlock, C. H.: LBA-HYD PC02 Surface/Top of the Atmosphere Shortwave Radiation Budget (SRB): CD-ROM, Data Set, Available at http://lba.cptec.inpe.br/ from LBA Data and Information System, National Institute for Space Research (INPE/CPTEC), Cachoeira Paulista, Sao Paulo, Brazil, 2006.

Laszlo, I., Pinker, R. T., and Whitlock, C. H.: Comparison of shortwave fluxes derived from two versions of the ISCCP products, in: IRS'96: Current Problems in Atmospheric Radiation, edited by: Smith, W., A. Deepak Publishing, Hampton, Virginia, USA, 762-765, 1997.

Malmström, C. M., Thompson, M. V., Juday, G. P., Los, S. O., Randerson, J. T., and Field, C. B.: Interannual variation in global scale net primary production: Testing model estimates, Global Biogeochem. Cy., 11, 367-392, 1997.

Martens, C. S., Shay, T. J., Mendlovitz, H. P., Matross, D. M., Saleska, S. R., Wofsy, S. C., Woodward, W. S., Menton, M. C., De Moura, J. M. S., Crill, P. M., De Moraes, O. L. L., and Lima, R. L.: Radon fluxes in tropical forest ecosystems of Brazilian Amazonia: night-time $\mathrm{CO}_{2}$ net ecosystem exchange derived from radon and eddy covariance methods, Glob. Change Biol., 10(5), 618-629, 2004.

Monteith, J. L.: Solar radiation and productivity in tropical ecosystems, J. Appl. Ecol., 9, 747-766, 1972.

New, M. G., Hulme, M., and Jones, P. D.: Representing twentiethcentury space-time climate variability. Part II: Development of 
1901-1996 monthly grids of terrestrial surface climate, J. Climate, 13, 2217-2238, 2000.

Olson, R. J., Scurlock, J. M. O., Cramer, W., Parton, W. J., and Prince, S. D.: From Sparse Field Observations to a Consistent Global Dataset on Net Primary Production, IGBP-DIS, Toulouse, France, Working Paper No. 16, 1997.

Parton, W. J., McKeown, B., Kirchner, V., and Ojima, D.: CENTURY Users Manual, Natural Resource Ecology Laboratory, Colorado State University, Fort Collins, 35 pp., 1992.

Potter, C. S.: Terrestrial biomass and the effects of deforestation on the global carbon cycle, BioScience, 49, 769-778, 1999.

Potter, C., Tan, P., Kumar, V., Kucharik, C., Klooster, S., Genovese, V., Cohen, W., and Healey, S.: Recent history of largescale ecosystem disturbances in North America derived from the AVHRR satellite record, Ecosystems, 8(7), 808-827, 2005.

Potter, C., Klooster, S., Steinbach, M., Tan, P., Kumar, V., Shekhar, S., and Carvalho, C.: Understanding global teleconnections of climate to regional model estimates of Amazon ecosystem carbon fluxes, Glob. Change Biol., 10, 693-703, 2004.

Potter, C., Klooster, S., Myneni, R., Genovese, V., Tan, P., and Kumar, V.: Continental scale comparisons of terrestrial carbon sinks estimated from satellite data and ecosystem modeling 1982-98, Global Planet. Change, 39, 201-213, 2003.

Potter, C. S., Brooks-Genovese, V., Klooster, S. A., and Torregrosa, A.: Biomass burning emissions of reactive gases estimated from satellite data analysis and ecosystem modeling for the Brazilian Amazon region, J. Geophys. Res., 107(D20), 8056, 10.1029/2000JD000250, 2002.

Potter, C. S., Klooster, S., de Carvalho, C. R., Brooks-Genovese, V., Torregrosa, A., Dungan, J., Bobo, M., and Coughlan, J.: Modeling seasonal and interannual variability in ecosystem carbon cycling for the Brazilian Amazon region, J. Geophys. Res., 106(D10), 10 423-10 446, 2001.

Potter, C. S., Bubier, J., Crill, P., and LaFleur, P.: Ecosystem modeling of methane and carbon dioxide fluxes for boreal forest sites, Can. J. Forest Res., 31, 208-223, 2001.

Potter, C. S., Klooster, S. A., and Brooks, V.: Interannual variability in terrestrial net primary production: Exploration of trends and controls on regional to global scales, Ecosystems, 2, 36-48, 1999.

Potter, C. S., Davidson, E. A., Klooster, S. A., Nepstad, D. C., de Negreiros, G. H., and Brooks, V.: Regional application of an ecosystem production model for studies of biogeochemistry in Brazilian Amazonia, Glob. Change Biol., 4(3), 315-334, 1998.

Potter, C. S., Randerson, J. T., Field, C. B., Matson, P. A., Vitousek, P. M., Mooney, H. A., and Klooster, S. A.: Terrestrial ecosystem production: A process model based on global satellite and surface data, Global Biogeochem. Cy., 7, 811-841, 1993.

Prentice, I. C. and Lloyd, J.: C-quest in the Amazon basin, Nature, 396, 619-620, 1998.
Priestly, C. H. B. and Taylor, R. J.: On the assessment of surface heat flux and evaporation using large-scale parameters, Mon. Weather Rev., 100, 81-92, 1972.

Rahman, A. F., Sims, D. A., Cordova, V. D., and El-Masri, B. Z.: Potential of MODIS EVI and surface temperature for directly estimating per-pixel ecosystem C fluxes, Geophys. Res. Lett., 32, L19404, doi:10.1029/2005GL024127, 2005.

Running, S. W. and Nemani, R. R.: Relating seasonal patterns of the AVHRR vegetation index to simulated photosynthesis and transpiration of forests in different climates, Remote Sens. Environ., 24, 347-367, 1998.

Saleska, S. R., Miller, S. D., Matross, D. M., Goulden, M. L., Wofsy, S. C., da Rocha, H. R., de Camargo, P. B., Crill, P., Daube, B. C., de Freitas, H. C., Hutyra, L., Keller, M., Kirchhoff, V., Menton, M., Munger, J. W., Pyle, E. H., Rice, A. H., and Silva, H.: Carbon in Amazon forests: Unexpected seasonal fluxes and disturbance-induced losses, Science, 302, 1554-1557, 2003.

Tian, H. Q., Melillo, J. M., Kicklighter, D. W., McGuire, A. D., Helfrich, J. V. K., Moore, B., and Vorosmarty, C. J.: Effect of interannual climate variability on carbon storage in Amazonian ecosystems, Nature, 396, 664-667, 1998.

Turner, D. P., Ritts, W. D., Cohen, W. B., Maeirsperger, T. K., Gower, S. T., Kirschbaum, A., Running, S. W., Zhao, M., Wofsy, S. C., Dunn, A. L., Law, B. E., Campbell, J. C., Oechel, W. C., Kwon, H. J., Meyers, T. P., Small, E. E., Kurc, S. A., and Gamon, J. A.: Site-level evaluation of satellite-based global terrestrial gross primary production and net primary production monitoring, Glob. Change Biol., 11, 666-684, 2005.

Van der Werf, G. R., Randerson, J. T., Collatz, G. J., and Giglio, L.: Carbon emissions from fires in tropical and subtropical ecosystems, Glob. Change Biol., 9(4), 547-562, 2003.

Xiao, X., Zhang, Q., Braswell, B., Urbanski, S., Boles, S., Wofsy, S., Moore, B., and Ojima, D.: Modeling gross primary production of temperate deciduous broadleaf forest using satellite images and climate data, Remote Sens. Environ., 91, 256-270, 2004.

Zhang, Q., Xiao, X., Braswell, B., Linder, E., Baret, F., and Moore, B.: Estimating light absorption by chlorophyll, leaf and canopy in a deciduous broadleaf forest using MODIS data and a radiative transfer model, Remote Sens. Environ., 99 (3), 357-371, 2005.

Zeng, N., Yoon, J.-H., Marengo, J. A., Subramaniam, A., Nobre, C. A., Mariotti, A., and Neelin, J. D.: Causes and impacts of the 2005 Amazon drought, Environ. Res. Lett., 3, 014002, doi:10.1088/1748-9326/3/1/014002, 2008.

Zheng, D., Prince, S., and Wright, R.: Terrestrial net primary production estimates for $0.5^{\circ}$ grid cells from field observations - A contribution to global biogeochemical modeling, Glob. Change Biol., 9, 46-64, 2003. 